\title{
TUBEROUS XANTHOMATOSIS
}

\author{
BY \\ DUNCAN LEYS \\ From the Padiatric Unit, Farnborough Hospital, Kent \\ Received April 24, 1950
}

Tuberous xanthomatosis is a rare condition, with dominant inheritance, but it is possible that its victims, who commonly show visceral and particularly cardiac atheroma, possess in homozygous form one or more genes that are fairly widely distributed and expressed, when heterozygous, as hypercholesteræmia and coronary atheroma without xanthomatosis (Bloom, Kaufman, and Stevens, 1947). The importance of the condition may therefore be out of proportion to the rarity of its occurrence, and this possibility is one reason for recording the history of a family in which it occurs. A second reason is the development in one of the child victims of the disease of intermittent claudication and the Stokes-Adams syndrome.

\section{HISTORY OF THE FAMILY}

Mrs. M., a widow of 46 years, with two surviving children, was first examined in November, 1938, when my opinion was sought for attacks of vomiting and abdominal pain which had been recurring at intervals of a few weeks for some years. The menopause had occurred in September, 1938. She was a stout woman (height 66 in., weight $196 \mathrm{lb}$.) with pronounced xanthelasma of the eyelids which she reported to have been present in her mother also: she had no other xanthomatous lesion. There was a moderate hypertension (170/110). Her pain suggested gall bladder disease but the cholecystogram was normal. The blood cholesterol was $137 \mathrm{mg}$ : per $100 \mathrm{ml}$. She had never been jaundiced.

She was not seen again until 1940, when she was admitted to hospital with acute bronchitis. She was orthopnœic and complained of severe substernal pain: the blood pressure had fallen to $70 / 50$ but rose after a few days to 110/75. Her cardiogram showed left axis deviation, with some slurring but no definite deviation of S-T, and no T inversion (leads I, II, III, IVR). The P-R interval was $0.22 \mathrm{sec}$.; Q-T, 0.36 ; and the rate, 96 . She made a good recovery from this attack, and had no further symptoms of coronary disease: her cardiogram was repeated in 1944, and showed the same features.

Her husband had died suddenly in 1935, at the age of 42 , after bathing; he had been a keen football player, but gave up the game at the time when he also changed from manual to sedentary work: as a result, he bacame stout. Her brother had lost two children in separate bathing accidents.

Mrs. M. had three children. The first (Case 1), died suddenly at the age of 12 . I am indebted to Drs. Ian MacLeod and J. H. Kirkpatrick for the following information about Case 1, and the remaining children (Cases 2 and 3) were examined by me in 1942.

Case 1. M. M. until her twelfth year had seemed a healthy child, but had become rather fat, and for some years her mother had noticed nodules over the tendons at the ankle: they were not painful. At the age of twelve she had an attack characterized by sudden loss of consciousness, cyanosis, deep sighing respiration, and incontinence of urine: there was no clonic or tonic spasm of the limbs or face. 
She made a quick recovery from the attack and had no residual symptoms. A second attack followed after a few days; there was no obvious association with exertion. When examined, she was found to have xanthomatous nodules on the legs, and patches of xanthoma on the face and buttocks. Her blood cholesterol was found to be more than $300 \mathrm{mg}$. per $100 \mathrm{ml}$. a few days before her third attack, which was fatal.

This child died at home, but a necropsy was performed by Dr. Kirkpatrick, and showed the lumina of the coronary arteries reduced to pin-point size from diffuse atheroma, which was also present in the aorta. There was no definite cardiac infarct. The trachea was studded with small xanthomatous nodules.

Case 2. A.M., the elder boy, was thirteen. Weight, $86 \mathrm{lb}$.; height, 56 in. He was freckled, but no xanthomatous lesions were seen. Physical examination was negative and the cardiogram normal (P-R, 0.16 sec.; QRS, 0.08; Q-T, 0.28, and rate 108). His blood cholesterol was $342 \mathrm{mg}$. per $100 \mathrm{ml}$. He was re-examined in 1944, when his blood cholesterol was $220 \mathrm{mg}$. per $100 \mathrm{ml}$.: the cardiogram was again normal and no abnormal physical signs were found.

Case 3. J.M., the younger boy, was twelve. He also was freckled and rather plump (height 54 in.; weight $72 \mathrm{lb}$.) He had no xanthomatous lesions, but a yellowish hairy nævus on the forearm. Physical examination was negative. His blood cholesterol was $322 \mathrm{mg}$. per $100 \mathrm{ml}$. His cardiogram (standard leads only) showed sinus rhythm, normal axis, P-R 0.18, QRS 0.08, Q-T 0.4 sec., rate 72 , and a biphasic $\mathrm{T}$ in leads I and II.

The following year (1943) I was called to see him because of attacks of syncope. He had complained for some months of tingling in the feet and pain in the calves when running, and of weakness in the legs that sometimes made him stumble. Shortly before I saw him, he lost consciousness when he was on his way home from school, but recovered after a few minutes. The following afternoon he had a "spasm" of the hands and feet which his doctor thought not unlike tetany, and again lost consciousness for some minutes: a similar attack occurred later in the day. Two days later, the spasm was repeated, but without loss of consciousness, lasting about five minutes. For the next week he seemed well, but one morning complained of headache on waking: after dressing he went out, but immediately afterwards had a generalized epileptic fit lasting ten minutes. He was examined later the same day and admitted to hospital.

On re-examination (1943) he was symptomless. The heart was regular, the sounds normal, and there were no murmurs. Blood pressure, 110/80. Pulsation could be easily felt in both arteries of the feet. No abnormal signs were found in the nervous system, and an X-Ray of the chest was normal. Blood cholesterol, 322, calcium 9.4, sodium 320, potassium $20 \mathrm{mg}$. per $100 \mathrm{ml}$. During his two weeks' stay in hospital, he felt quite well and had none of his previous symptoms. Arterial biopsy was performed by Mr. A. J. Hamilton, and photomicrographs of sections taken from this specimen are reproduced in the figure. I am indebted to Dr. H. J. Kirkpatrick, pathologist to the Royal Northern Infirmary, Inverness, for the following reports of sections, the first being stained with hæmatoxylin-eosin.

"The Media. The muscle fibres are separated by fine collagen fibrils and by deposits of globules, probably of lipoid. Many of the muscle fibres show degenerative changes: some are atrophic, others are swollen and stain poorly, and in a few the muscle substance is largely replaced by fatty material.

"The Intima. There is patchy thickening of the intima due to increase in fibrous tissue and fat deposits. The fibrous tissue is undergoing degeneration, and in the thicker parts it has a granular, rather amorphous appearance. The endothelium is for the most part intact but an occasional endothelial cell is distended by fat.

"The Adventitia. The adventitia is moderately thickened and there is occasional deposit of fatty material close to the media.

"Sections stained with Verheoff-Van Giesen. The internal elastic lamina forms a single layer and is complete; in one or two places the lamina shows commencing degeneration. There is no stainable elastic tissue in the media. There is no apparent abnormality of the elastic tissue of the adventitia. 

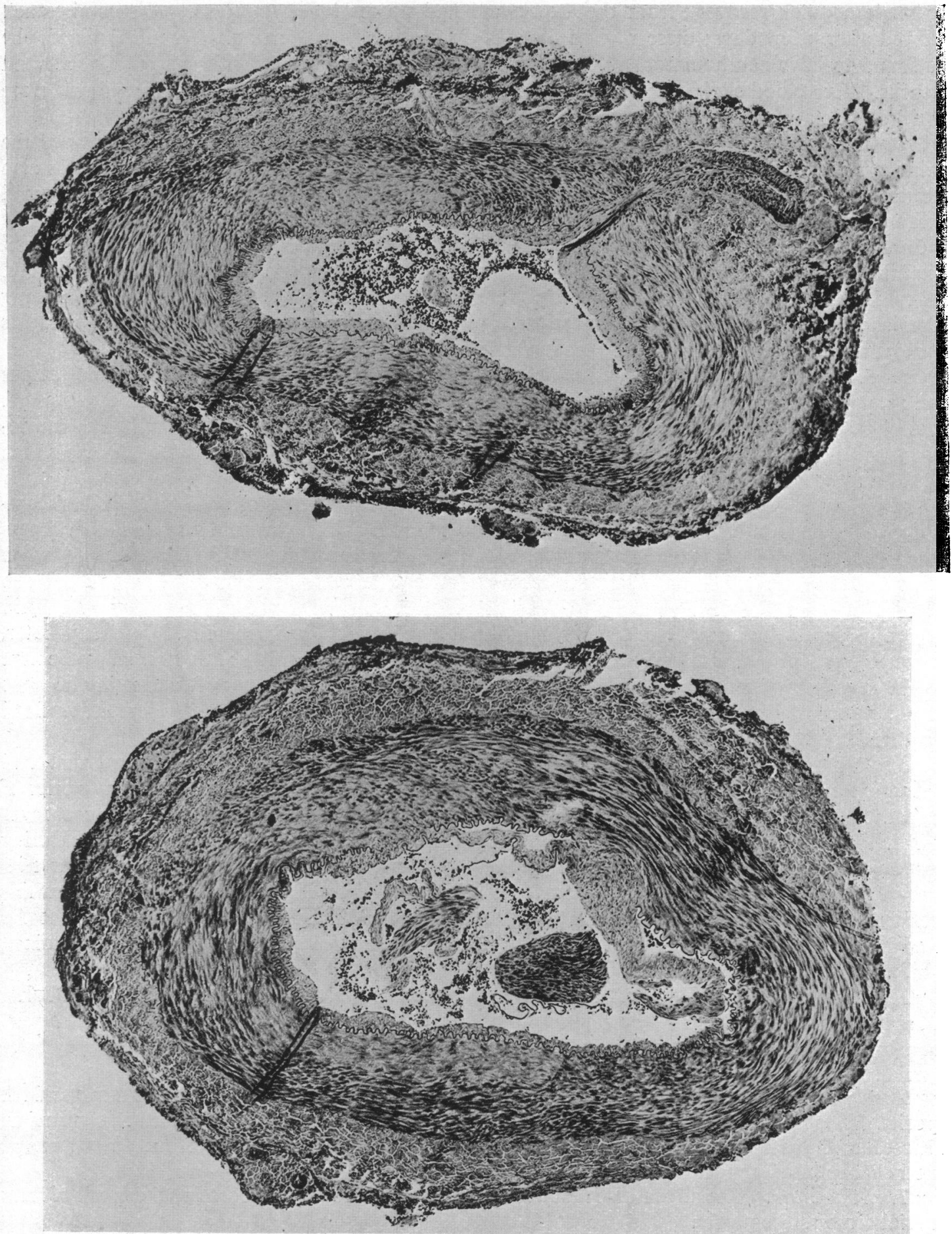

FIG. 1.-Photomicrographs of biopsy specimen from artery of medium calibre from Case 3, aged 13. $(\times 50)$. The intima is irregularly thickened; muscle fibres of the media are separated by lipoid, also present within the fibres and in the intima. Connective tissue is increased in the media and is the site of fatty degeneration. 
"There was not enough tissue for frozen sections for fat stains and examination by polarized light, but I think it fairly clear that the deposit in the vessel wall is of lipoid or fatty material."

Subsequent Progress. During the following year he was seen from time to time and remained symptomless except for discomfort in his legs when active. His blood cholesterol remained high, and was not influenced by low-fat diet or by thyroid extract 3 grains daily. The following figures were obtained, the lowest bearing no clear relation to thyroid treatment; $294,332,192,256,270$, $332,268,228,272,348 \mathrm{mg}$. per $100 \mathrm{ml}$. In 1945 he was readmitted to hospital after a prolonged epileptic attack: mental dulling was evident, but slowly improved. There were no residual signs to suggest a focal origin. No evidence of xanthomatosis had appeared. This boy was last seen in 1946, apparently well, and is now (1949) reported as symptomless and working as a van driver. Since 1945 he has taken each day 1.5 grains of thyroid extract and 1.5 grains of phenobarbitone. The important features of this boy's cardiograms are shown below. In October, 1943, the only abnormal symptom or sign was the high blood cholesterol: his 1942 cardiogram is normal except for the biphasic T. In 1943, after his first syncopal attack, TIV is inverted, but the most remarkable feature is the duration of Q-T, which is almost 0.5 second, with a heart rate of 90 . Thereafter his Q-T interval is always prolonged. TIV reverts to upright until the 1947 record, taken at a time when I was no longer in touch with him: the Q-T in this record is 0.45 seconds, with a heart rate of 90 . S-T shows no significant deviation throughout the records.

\begin{tabular}{|c|c|c|c|c|c|c|c|c|c|c|c|c|}
\hline $\begin{array}{l}\text { Date } \\
\text { October } 1942 \\
\text { December } 1943 \\
\text { January } 1947\end{array}$ & $\begin{array}{l}\because \\
\because \\
\cdots\end{array}$ & $\begin{array}{l}. \\
. .\end{array}$ & $\begin{array}{l}. . \\
\because .\end{array}$ & $\begin{array}{l}\text { Rate } \\
75 \\
90 \\
90\end{array}$ & $\begin{array}{l}\text { P-R } \\
0 \cdot 18 \\
0 \cdot 16 \\
0 \cdot 17\end{array}$ & $\begin{array}{l}\text { QRS } \\
0.07 \\
0.08 \\
0.07\end{array}$ & $\begin{array}{l}Q-T \\
0 \cdot 36 \\
0 \cdot 50 \\
0.46\end{array}$ & $\begin{array}{c}\text { TI } \\
\uparrow \\
\uparrow \\
\uparrow\end{array}$ & $\begin{array}{c}\text { TII } \\
\uparrow \\
\uparrow \\
\uparrow \\
\uparrow\end{array}$ & 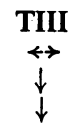 & $\frac{\text { TIV }}{\downarrow}$ & \\
\hline Fe"” " "̈ & $\begin{array}{l}\cdots \\
\cdots\end{array}$ & $\begin{array}{l}. . \\
.\end{array}$ & $\begin{array}{l}. \\
. \cdots\end{array}$ & $\begin{array}{l}90 \\
90 \\
90\end{array}$ & $\begin{array}{l}0.16 \\
0.16 \\
0.16\end{array}$ & $\begin{array}{l}0.08 \\
0.08 \\
0.08\end{array}$ & $\begin{array}{l}0.40 \\
0.40 \\
0.42\end{array}$ & & & & $\begin{array}{l}\uparrow \\
\uparrow\end{array}$ & $\begin{array}{l}\text { Before exercise } \\
\text { After exercise } \\
\text { Before and after }\end{array}$ \\
\hline $\begin{array}{l}\text { August } 1944 \\
\text { January } 1945 \\
\text { January } 1946 \\
\text { February } 1947\end{array}$ & $\begin{array}{l}\because \\
\because \\
\cdots\end{array}$ & $\begin{array}{l}. \\
\because \\
. \\
.\end{array}$ & $\begin{array}{l}\because \\
\because \\
\because\end{array}$ & $\begin{array}{r}90 \\
105 \\
105 \\
100 \\
90\end{array}$ & $\begin{array}{l}0 \cdot 16 \\
0 \cdot 16 \\
0 \cdot 16 \\
0 \cdot 18\end{array}$ & $\begin{array}{l}0.08 \\
0.08 \\
0.08 \\
0.08\end{array}$ & $\begin{array}{l}0.40 \\
0.40 \\
0.44 \\
0.45\end{array}$ & $\underset{\substack{\uparrow \\
\uparrow}}{\stackrel{\leftrightarrow}{\uparrow}}$ & $\begin{array}{l}\uparrow \\
\uparrow \\
\uparrow \\
\uparrow\end{array}$ & $\begin{array}{l}\downarrow \\
\downarrow \\
\leftrightarrow \\
\leftrightarrow\end{array}$ & $\frac{\uparrow}{\uparrow}$ & exercise \\
\hline
\end{tabular}

\section{COMMENT}

Increase of the blood cholesterol occurs in such a variety of clinical syndromes that it has, as an isolated phenomenon, little value in diagnosis. Xanthosis is uncommon and distinctive. A familial tendency to atheroma and death from coronary disease is well recognized and represents one of the most important obstacles to longevity. High levels of the blood cholesterol in these cases are common, possibly invariable. I have records of several such families, of which the following is an example:

E.L., a postman, aged 40, developed angina when on active service, six months before I saw him in 1942, and was discharged from the army. His two sisters had died young, at ages 13 and 36. Two of his brothers had died suddenly, at ages 40 and 42 . He was an anxious man, fully conscious of the significance of his family history, and rather obese. No xanthomatous lesions were seen. His cardiogram, which had shown T inversion in one army hospital, was normal except for left axis deviation, but exercise produced some S-T deviation. His B.M.R. was normal. The blood cholesterol ranged from 210 to $280 \mathrm{mg}$. per $100 \mathrm{ml}$., but a few months later was $420 \mathrm{mg}$. In 1945 he collapsed and died while out walking. This man's surviving brother, aged 35, weighed $200 \mathrm{lb}$. Physical examination showed a broad aorta; his blood cholesterol was $236 \mathrm{mg}$. per $100 \mathrm{ml}$.

Coronary disease is rare in childhood. Extreme and unexplained calcification of the arteries may occur, even in infancy (Leys, 1950b). In later childhood the syndrome of lipoidosis is a possible cause. Unexplained sudden death in later childhood, especially when there is more than one victim in the family, suggests this syndrome, and sudden death suggestive of cardiac 
disease below the age of $\mathbf{4 0}$ demands a study of sibs and particularly of the children. The frequency of coronary obstruction as a cause of death is increasing and the age incidence decreasing. Occupational analysis suggests strain and hypertensive disease as main causes (Ryle and Russell, 1949), but any observation that tends to explain the mechanism of the atheromatous process must be of value.

The influence of diet in the genesis of lipoidosis and the relationship of increase in the blood fat to atheroma is undecided. This problem is briefly discussed and references given in my paper on the inheritance of a factor causing sudden death in adolescence (Leys, 1950a). The attempt to reduce the level of the blood cholesterol by thyroid treatment is logical in view of the accumulation of cholesterol in atheromatous lesions; although no good evidence was obtained of such a therapeutic effect in this case, it is suggestive, in view of his sister's story, that thyroid effected a diminution of tissue cholesterol in Case 3. The long Q-T in this boy is a distinctive finding and may well be a feature of such cases: it was not prolonged in either his mother or his brother.

\section{SUMMARY}

A family is reported in which xanthelasma appeared in two generations and, in the third, tuberous xanthomatosis leading to death from coronary disease of the eldest child at the age of 12 , and arterial claudication and the Stokes-Adams syndrome in the second, at the same age. Both these children, and the remaining boy showed hypercholesteræmia. It is suggested that the father of these children, who died suddenly at the age of 42 , may have been heterozygous for the gene and the children homozygous.

\section{REFERENCES}

Bloom, D., Kaufman, S. R., and Stevens, R. A. (1942). Arch. Derm. Syph., 45, 1. Leys, D. (1950a). Edinburgh med. J., 58, 1.

(1950b). To be published.

Ryle, J. A., and Russell, W. T. (1949). Brit. Heart J., 11, 370. 